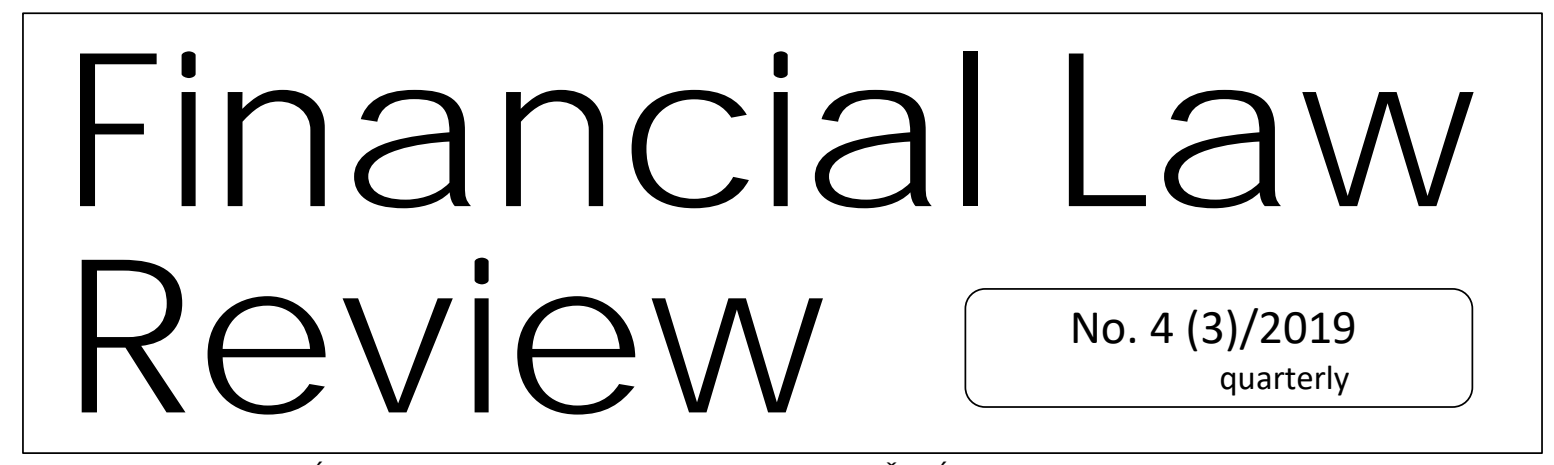

UNIVERSITY OF GDAŃSK • MASARYK UNIVERSITY • PAVEL JOZEF ŠAFÁRIK UNIVERSITY • UNIVERSITY OF VORONEZH http://www.ejoumals.eu/FLR

\title{
MEANING OF ACTIVITY OF ADJUDICATION COMMISSIONS IN CASES RELATED TO VIOLATION OF PUBLIC FINANCE DISCIPLINE IN POLISH LEGAL SYSTEM WOJCIECH BOŻEK *
}

\begin{abstract}
The author's goal is to identify the importance of the activity of adjudication commissions in cases related to violation of public finance discipline in polish legal system and to show the problems of non-effectiveness legal solutions in the system of liability for violating public finance discipline. In the author's opinion, this article belongs the stream of researches on the essence and range of liability for the violation of public finance discipline and it may be useful in the practice of financial law implementation. Several research methods are used in the study, including dogmatical, analytical, legal comparative and empirical method. The author comes to the conclusion that analysis of regulations included in the Act of 17 December 2004 indicates that subjective range of liability for the violation of public finance discipline is extensive and casuistic. Despite of recent changes, there is still an effect of incomplete regulation for all processes relating to public means collecting and disposing. The activity of the adjudicating commissions indicates that violations of the public finance discipline occur most often in the local government sector.
\end{abstract}

\footnotetext{
* PHD in law Wojciech Bożek, Department of Financial Law, Faculty of Law and Administration, Stettin University, Poland. Author specializes in financial law and local government finance. Contact email: wojciech.bozek@usz.edu.pl, https://orcid.org/0000-0002-3939-3759.
} 
A small number of decisions are appealed to the MAC. It is required to consequently and effectiveness extend liability for violation of public finance discipline over all entities who use public funds. Analysis of legal solutions of countries of the Europe: United Kingdom, France and Germany permitted to show complexity of problems accompanying to maintenance of financial discipline in these countries, and at the same time it is a starting point to indicate alternative solutions aimed to ensure order in public finances of these states.

Key words: public finance discipline; liability; violation; public finance sector

JEL Classification: H60; H70; H80

\section{Introduction}

Superior value, protected by the system of responsibility for violating public finance discipline in Poland, is order and safety of public finances. That is the most important purpose of the Act dated 17 December 2004 of liability for violating public finance discipline (hereinafter: Act of 17 December 2004), which constitutes a trial to comprehensively regulate all legal issues connected with executing liability for violating public finance discipline. Legal area regulated by the act is dynamic, and the process of changes will be continued during incoming years, because the system of liability for violating public finance discipline is not perfect yet, and the doctrine and the professional practical literature indicate numerous fields of its dysfunctionality.

The institution of the public finance discipline has been exercised in the Polish legal order only since 1999. Before, a narrower concept of the budgetary discipline was functioning in the polish public finances. However, it may be assumed that in the Polish legal order a specific legal regime was created to protect public resources, having separate rules - rules and course of conduction for collecting and for disposing of public means.

In this article, a thesis was assumed about essential role of first instance adjudication commissions and the Main Adjudication Commission (hereinafter: MAC or Commission) in the system of liability for violating public finance discipline, and in particular, their importance resulting from two-instance proceeding in above cases. Review of verdicts given by above mentioned commissions allowed identification of several functions of commissions, that is repressive, control, prevention, information (education, popularization). 


\section{General outline of liability for violation of public finance discipline in Poland}

The public finance discipline in Poland is connected with observance of legal standards that regulate processes of collecting and disposing public means in relation with performance of public tasks [Kosikowski 2003: 271]. In other approach, it should be understood as obligation to respect rules defined by law for public means disposal, as well as means from public resources, given to entities from outside of the public finance sector, that is an order in financial economy, rules of legality and economic efficiency defined by law and required for correct public finance management.

Despite of many similarities to penal, labour and administrative liability, the liability for violation of public finance discipline has different legal nature and some distinct structural elements [Borodo 2008: 260]. This liability is not identical to typical disciplinary and property accountability, neither. The argument that justifies administrative character of the Commission's verdicts is, as expressed in art. 169 of the act of $17^{\text {th }}$ December 2004, possibility of appealing to the administrative court. According to the above regulation, an appeal to the administrative court may be risen against, i.a. valid decisions being a sentence or resolution, that were issued by the Commission and finalized proceeding.

There are a lot of legal gaps in the system of liability for violating public finance discipline, that are threats for its correct functioning, deciding on its essential weaknesses and possible dysfunctionality. In the act of $17^{\text {th }}$ December 2004 there is no legal definition of "public finance discipline" or "violation of the discipline of public finances". In order to neutralize shortages in legal definitions, the legislator adapted solution consisting in formulation of an enclosed catalogue of acts that constitute the violation of public finance discipline [Gryska, Robaczyński 2006: ix-x]. This catalogue rises some controversy, since it does not cover all processes which occur in public finances.

Analysis of regulations included in the Act of $17^{\text {th }}$ December 2004 (art. 5-18c of this Act) indicates that subjective range of liability for the violation of public finance discipline is extensive and casuistic. Despite of recent changes, there is still an effect of incomplete regulation for all processes relating to public means collecting and disposing. For example, liability for not conducting or unreliable internal audit in the public finance sector unit is still not regulated [Bożek 2018: 324-335]. The division of public finance discipline violations include the following categories: in the range of public means collecting; in the range of public procurements; in the range of concession agreements; in the range of incurring and performing liabilities; other acts being the violation of public finance discipline [Ofiarski 2010: 435]. In the catalog of actions which constitute a violation of public finance discipline can indicate, among others: 
1) discontinuing execution and settlement of an inventory or conducting or settling an inventory in a manner inconsistent with the provisions of the Accounting Act of 29 September 1994 and failure to prepare or nonforward on time a report on the implementation of the processes of collecting public funds and their distribution (budgetary report) or showing data in this report that are inconsistent with the data resulting from accounting records, which are the most common group of violations in polish system of liability of violation of public finance discipline (art. 18 of the Act of $17^{\text {th }}$ December 2004, Decision of the MAC of September 10 $0^{\text {th }}, 2018$ );

2) an extensive catalog of violations implication of public procurement, including a dozen acts (art. $17 \mathrm{sec}$. 1-6 of the Act of $17^{\text {th }}$ December 2004), for example: infringement of the principle, form or procedure of conduct when awarding a public procurement (Decision of the MAC of October $11^{\text {th }}, 2018$ );

3) making expenditure from public funds without authorization specified in the Budgetary Act, budgetary resolution or financial plan, or with overstepping the scope of this authorization or in violation of the provisions concerning the individual types of expenses (art. $11 \mathrm{sec} .1$ of the Act of $17^{\text {th }}$ December 2004, Decision of the MAC of $19^{\text {th }}$ March 2018);

4) incurring or changing obligations without authorization specified in the Budget Act, budgetary resolution or financial plan, or overstepping the scope of this authorization or in violation of provisions regarding incurring or changing liabilities by the public finance sector unit (art. $15 \mathrm{sec}$. 1 of the Act of $17^{\text {th }}$ December 2004, Decision of the MAC of $22^{\text {nd }}$ January, 2018). 
Table 1. The results of investigation of the commissions of the first instance in the years 2012-2018 taking into account the Act of $17^{\text {th }}$ December 2004.

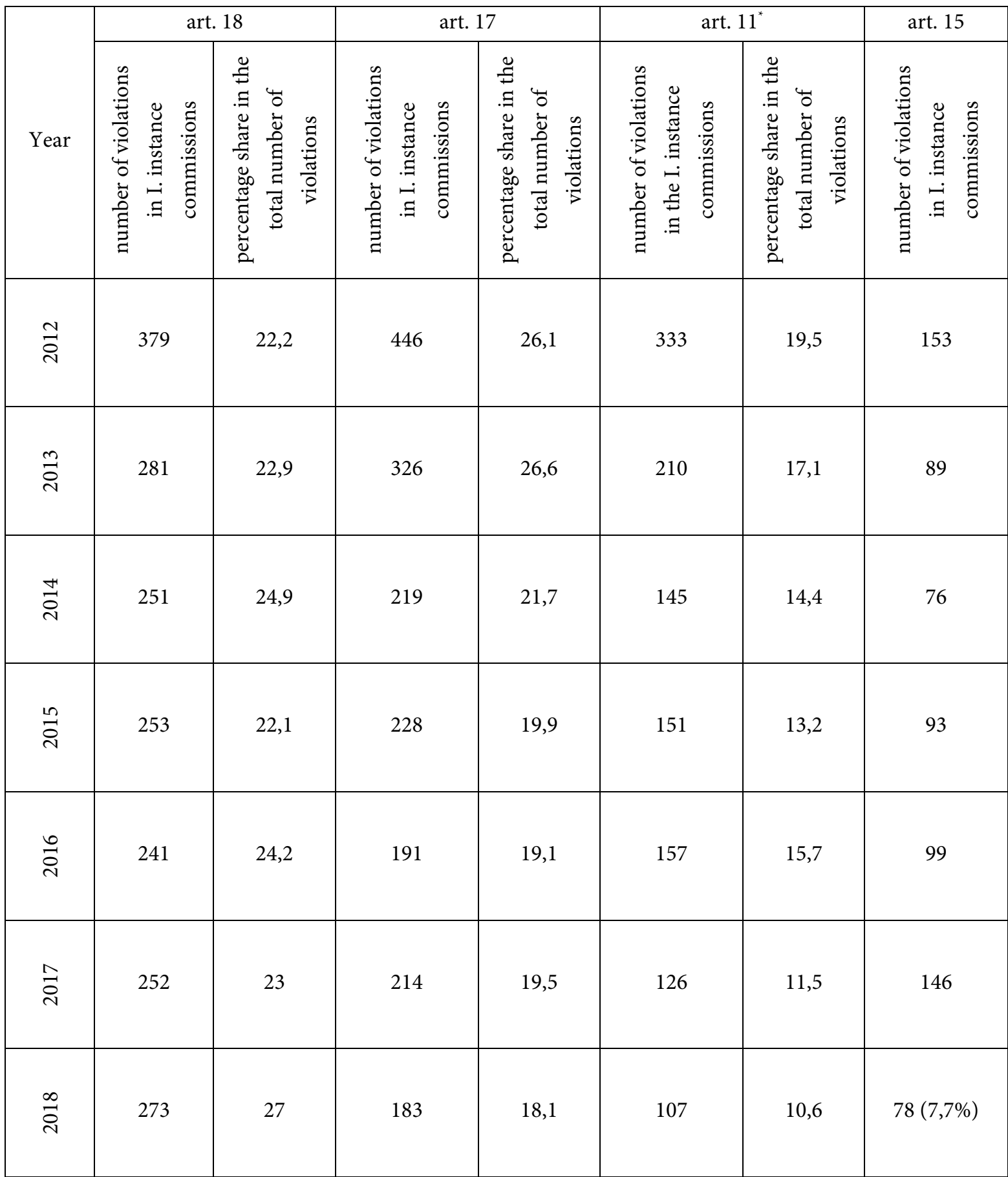

* in 2018 (only in this year) in 3rd place there were violations regarding disbursement of a grant contrary to the purpose determined by the grantor, non-settlement on time received grant, failure to refund the grant in due time (art. 9 of the Act of $17^{\text {th }}$ December 2004): 138 infringements, which constitutes $13.6 \%$ of all acts).

Source: own preparation based on the Summary of the audits of MAC and audits of adjudicating commissions of the first instance from the years 2012-2018, www.mf.gov.pl, entry: 28.05.2019. 
The catalog of violations of the public finance discipline includes behaviors detrimental to public finances, which are inconsistent with the provisions of law regulating the management of property and public funds [Miemiec 2011].

The principle is that liability for violating public finance discipline is borne both for actions and neglects, unless the violation could not have been avoided despite due diligence as required from persons responsible for the good of public finance [Lipiec-Warzecha 2012: 362-364]. This type of liability should be independent of other liabilities defined by provisions of the law, but in the event of instituting proceedings in the case of a crime, fiscal crime, offense or fiscal offense the same time constituting a violation of public finance discipline, proceedings over violation of public finance discipline should be suspended pending completion of the penal, fiscal penal or offense proceedings. Also in the event of instituting proceedings in the case of a crime, fiscal crime, offense or fiscal offense at the same time being a violation of public finance discipline, the instituted proceedings over violation of public finance discipline should be discontinued (Decision of the MAC of October $\left.8^{\text {th }}, 2015\right)$.

There is four penalties for violating public finance discipline in polish legal system of liability of violation of public finance discipline: an admonition, a reprimand, a cash penalty and a ban on performance of functions connected with disposing of public funds (hereinafter: a ban on performance of functions), for a period of 1-5 years from the day of validation of the adjudicating decision. It need to be said that all of this penalties are not adequate to subjective scope of this system, for example to persons acting on behalf of an entity not included in the public finance sector, who have been authorized to use or dispose of public funds and activities related to the use of these funds or disposing of these funds. It is necessary to know that not only chief of public finance sector entities and employees of the public finance sector are liable for violating discipline of public finances. Other persons with public funds at their disposal, including persons responsible for management of public funds transferred to entities outside the public finance sector, could be liable for violating discipline of public finances too [Salachna 2006: 30-34]. The abovementioned penalties will not fulfill their repressive and preventive functions towards these persons. It should be borne in mind that in this system of liability the committee adjudicating in cases over violation of public finance discipline should measure out the penalty at its own discretion, within the limits envisaged in the Act, taking into consideration the degree of the fault and the effects and degree of harmfulness of the behavior for order of public finances, with due regard for the purposes of the penalty in its social impact and the preventive and educational purposes that it is to achieve for the punished person. It is necessary respect the rule that circumstances affecting the penalty need to be taken into consideration only as regards the person they concern [Ostaficzuk 2012: 149-162]. 
Chart 1. Number of fines imposed for violation of public finance discipline in polish legal system of liability of violation of public finance discipline in 2012-2018.

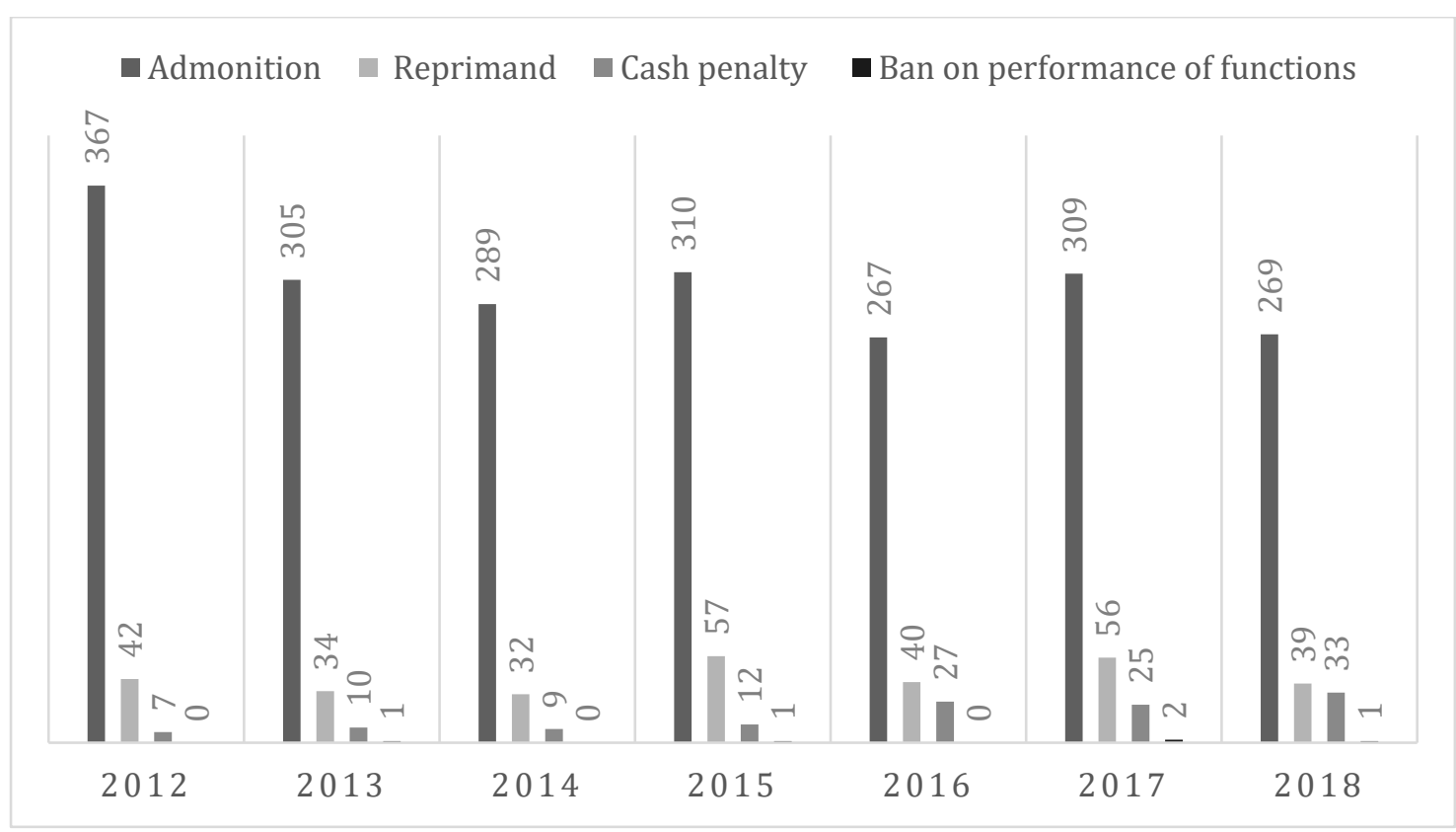

Source: own preparation based on the Summary of the audits of MAC and audits of adjudicating commissions of the first instance from the years 2012-2018, www.mf.gov.pl, entry: 28.05.2019.

The number of penalties imposed for violation of public finance discipline in 2012-2018 in the chart 1 shows that most popular in this system is an admonition (between $78 \%$ to $88 \%$ cases of imposed penalties). It should be borne in mind that this type of penalty is not associated with any specific consequences for the perpetrator of the violation. It is the mildest type of penalty in the catalog of penalties for violation of the public finance discipline. In 2012-2018 there were only 5 cases when adjudication commissions imposed a ban on performance of functions. In above mentioned catalog of penalties it is the most repressive type of them but very rarely used. It can be said, that adjudication commissions in a system of liability of violation of public finance discipline created a liberal and careful judicial attitude.

\section{The structure of legal system of liability of public finance discipline}

Proceedings in cases related to the violation of public finance discipline include ordered sequence of activities, that compose a process aimed to decide by competent authorities about liability for such violation. In proceeding in cases concerning the violation of public finance discipline, the defendant has possibility to effectively exercise rights guaranteed in the constitution. Proceedings in cases concerning violation of public finance discipline 
consists of two instances. It can be distinguished four types of the adjudicating commission of the first instance [Misiąg 2019]:

1) the joint adjudicating commission (JAC);

2) the adjudicating commission next to the Chief of the Chancellery of the Prime Minister (AC next to CCPM),

3) interministerial adjudicating commissions (IAC) functioning at:

a) minister competent for public finances,

b) minister competent for public administration,

c) Minister of Justice;

4) regional adjudicating commissions in cases concerning violation of public finance discipline next to regional accounting offices (RAC).

Members of adjudicating commissions in cases concerning violation of public finance discipline are independent within the scope of adjudication and subordinated only to laws.

The adjudicating body in cases concerning violation of public finance discipline of the second instance is the MAC in cases of violation of public finance discipline. The Commission genesis indicates close relations of the body with the Ministry of Finances that provides premises, legal and organizational-technical services for the Commission, and also covers, for example, expenses relating to its functioning. Therefore, administrative supervision of the Minister of Finances over the Commission results from financing Commission activities from public means and realization by the Commission tasks appropriate to competences of the Minister of Finances.

According to the two-instance rule, the Commission investigates, among others, appeals against the commission verdicts in the first instance, what means that the body which recognizes the case is bound in the appealing procedure by the limits of appeal means. The Main Adjudication Commission is an essential component of the public finance sector that influence standards of its functioning, especially including legal course of public means collecting and disposing. However, attention should be drawn to the small number of decisions made by the I instance committee appealed to the MAC (table 2). 
Table 2. The total number of decisions in the I. instance commissions divided into individual types of commissions and the total number of decisions of MAC.

\begin{tabular}{|c|c|c|c|c|c|c|c|}
\hline Year & $\begin{array}{c}\text { total number of } \\
\text { decisions in I. } \\
\text { instance } \\
\text { commissions }\end{array}$ & RAC & $\begin{array}{c}\text { percentage } \\
\text { of RAC }\end{array}$ & IAC & $\begin{array}{c}\text { AC next to } \\
\text { CCPM }\end{array}$ & JAC & $\begin{array}{c}\text { total number of } \\
\text { decisions MAC }\end{array}$ \\
\hline 2012 & 1517 & 1385 & $91,30 \%$ & 132 & 0 & 0 & 131 \\
\hline 2013 & 1160 & 1001 & $86,29 \%$ & 157 & 1 & 1 & 122 \\
\hline 2014 & 1186 & 1021 & $86,09 \%$ & 159 & 3 & 3 & 122 \\
\hline 2015 & 1199 & 1025 & $85,49 \%$ & 173 & 1 & 0 & 130 \\
\hline 2016 & 1185 & 1067 & $90,04 \%$ & 117 & 1 & 0 & 132 \\
\hline 2017 & 1127 & 952 & $84,47 \%$ & 172 & 1 & 2 & 116 \\
\hline 2018 & 1063 & 892 & $83,91 \%$ & 169 & 2 & 0 & 160 \\
\hline
\end{tabular}

Source: own preparation based on the Summary of the audits of MAC and audits of adjudicating commissions of the first instance from the years 2012-2018, www.mf.gov.pl, entry: 28.08.2019.

Table 2 shows that most of the cases adjudicated by the first instance committees in cases concerning violation of public finance discipline concerned violations at the level of selfgovernment units of the public finance sector. The appropriate to settle in the abovementioned matters are RAC. That is why it is so important in the Polish financial law system to strive to raise the qualifications of those responsible for collecting and spending public funds, especially at the local government level. The scope of issues resolved by the $\mathrm{RAC}$ is extensive, since the list of acts constituting violation of the public finance discipline is, due to its casuistic nature, very large. Few of these cases are appealed to the MAC.

\section{The results of the analysis of regulations concerning discipline of public finances in selected European countries}

Review of legal solutions in three countries of the Europe: United Kingdom, France and Germany, indicates that separate and particular course of liability connected with the violation of financial discipline within financial system in legislation of other countries is used marginally. The most extensive legal regulations concerning financial discipline has the French financial system. These regulations basically apply to control of the state budged realization and to local government units. The French legal order distinguishes a category of financial jurisdiction, that is a separate and specialized type of administrative jurisdiction. The law that regulate the legal position and functioning of the Court, as well as the actes which are breaches of public finance discipline, and the sanctions for them, is the Code of finance jurisdiction [Cilak 2014: 74-76]. The most important element of the system of jurisdiction in financial matters, that constitute a specialized type of administrative jurisdiction is the Court of Budgetary and Finance Discipline in France jurisdiction, which 
covers the cases of serious breach of public finance law. Much more difficult is comparison polish regulations to the British and German solutions, as in these countries the violation of public finances discipline is not regulated separately. However, in each of the said countries there are some alternative public institutions provided with financial and legal instruments that are aimed to ensure observance of regulations that regulate procedures of public means - collecting and disposing [Bożek 2016: 355-358, Ruśkowski, Ostrowska 2010: 186-188].

The analysis of legal solutions adopted in three selected countries of the European shows that discussion of main political and legal solutions and administrative structure are still actually, especially in area public finance discipline. Analysis of legal solutions of this countries permitted to show complexity of problems accompanying to maintenance of financial discipline in these countries, and at the same time it is a starting point to indicate alternative solutions aimed to ensure order in public finances of these states. On this area we can see equally, uniqueness of solutions adapted in the Polish act of $17^{\text {th }}$ December 2004 was demonstrated. Analysis of legal orders in the selected European states indicates increasing importance of $3 \mathrm{E}$ criteria and value for money in evaluation of efficient functioning of the public finance sector units. Economy, efficiency and effectiveness of the unit control favours correct financial management.

\section{Conclusions}

The system of liability for violation of public finance discipline in Poland is still evolving. The analysis of verdicts of I. instance commissions and the Commission allow to formulate many conclusions that indicate the need to increase effectiveness of managements and supervision over the public finance sector units, so that basic rules of public means management are not infringed in the future. Present model of liability for the violation of public finance discipline does not fully and efficiently protect the order and security of public finances, therefore, further changes of some elements of the liability system are needed. However, it may be said that the Act of $17^{\text {th }}$ December 2004 creates a model and mechanisms that foster correct functioning of the public finance sector units. It is required to consequently extend liability for violation of public finance discipline over all entities that are responsible for performing control and supervision functions over the public finances sector units, which may interfere with lawful collecting and disposing of public means.

Regional adjudication commissions perform important tasks in the field of general and individual prevention. In particular, RACs are important elements in the structure of the liability system for violating public finance discipline. In proceedings before the RAC, violations related to the obligation to conduct an inventory and conduct reporting in self- 
government units of the public finance sector are of the most common type, as well as breaches of public procurement regulations and spending public funds.

The adjudicating commissions and the MAC should adjudicate taking into account the repressive character of the penalties as well as the preventive and educational nature of the proceedings in cases concerning violation of the public finance discipline.

\section{References:}

Borodo, A., Budget Law, Warsaw: LexisNexis Poland, 2008.

Bożek, W., Failure to conduct an internal audit - the premise violation of public finance discipline, Finanse Komunalne [Municipal Finances] 2018, No. 3. The publication in an electronic version is available at: https://www.nik.gov.pl/plik/id,18298.pdf.

Bożek, W. Adjudication activity of the Main Adjudication Commission in cases related to violation of public finance discipline analysis of main trends in arbitrating output in years 2010-2015, Szczecin: University of Szczecin, 2016.

Cilak, M. The Legal Solutions in the Field of Financial and Budgetary Discipline in France in the Light of the Code of Finance Jurisdiction, Prawo Budżetowe Państwa i Samorządu [Budget Law of the State and Local Government] 2014, No. 1.

Gryska, P., Robaczyński, T., Discipline of public finances. Commentary, Warsaw: C.H. Beck, 2006.

Kosikowski, C., Financial law. General part, Warsaw: ABC Publishing House, 2003.

Lipiec-Warzecha, L., Responsibility for violation of public finance discipline. Commentary, Warsaw: WoltersKluwer, 2012.

Misiąg, W. (ed.), Act on liability for violation of public finance discipline [in] Misiąg W. (ed.), The Public Finance Act. Act on liability for violation of public finance discipline. Commentary, Legalis 2019

Ofiarski, Z., Financial law, Warsaw: C.H. Beck, 2010.

Ostaficzuk, M., Comparative analysis of the catalog of penalties from the penal fiscal code and the act on liability for violation of public finance discipline, (in:) Bojkowski T., Przybylska J. (ed.), Discipline of public finances. Principles of responsibility, judicial problems and practical aspects, Warsaw: CeDeWu, 2012.

Ruśkowski, E., Ostrowska, A., Models of supervision and control over the municipal finance system in selected EU countries. Introductory remarks, (in:) M. Stec (ed.), Regional Accounting Chambers. Political characteristics and commentary to the Act, Warsaw: WoltersKluwer, 2010.

Salachna, J., Defining the subjective scope of responsibility for violation of the public finance discipline at the level of local government units - selected problems, Przegląd Podatków Lokalnych i Finansów Samorządowych [Review of Local Taxes and Local Finances] 2006, No. 1. 


\section{Legal Acts:}

Act dated $17^{\text {th }}$ December 2004 of liability for violating public finance discipline (consolidated text: Journal of Laws of 2019, item 1490).

Act dated $29^{\text {th }}$ September 1994 on Accounting (consolidated text: Journal of Laws of 2018, item 395, 398 and 650).

\section{Administrative Acts:}

Decision of the MAC of $19^{\text {th }}$, March 2018, BDF1.4800.2.2018, Legalis no 1889573.

Decision of the MAC of 22 ${ }^{\text {nd }}$, January, 2018, BDF1.4800.70.2017, Legalis no 1895261.

Decision of the MAC of October 11 $1^{\text {th }}, 2018$, BDF1.4800.77.2018, Legalis no 1895823.

Decision of the MAC of October $8^{\text {th }}$, 2015, BDF1.4800.72.2015, www.mf.gov.pl (entry: 3.08.2019).

Decision of the MAC of September 10 ${ }^{\text {th }}, 2018$, BDF1.4800.62.2018, Legalis no 1894641.

\section{Internet Resources:}

Summary of the audits of MAC and audits of adjudicating commissions of the first instance from the years 2012-2018, www.mf.gov.pl, entry: 28.07.2019. 